\title{
Be Free? The European Union's post-Arab Spring Women's Empowerment as Neoliberal Governmentality
}

\section{HENDRIK HUELSS}

School of Politics and International Relations, University of Kent, Canterbury, Kent CT2 7NR

E-mail: h.c.huelss@kent.ac.uk

\begin{abstract}
This article analyses post-Arab Spring EU initiatives to promote women's empowerment in the Southern Mediterranean region. Inspired by Foucauldian concepts of governmentality, it investigates empowerment as a technology of biopolitics that is central to the European neoliberal model of governance. In contrast to dominant images such as normative power Europe that present the EU as a norm-guided actor promoting political liberation, the article argues that the EU deploys a concept of functional freedom meant to facilitate its vision of economic development. As a consequence, the alleged empowerment of women based on the self-optimisation of individuals and the statistical control of the female population is a form of bio-power. In this regard, empowerment works as a governmental technology of power instead of offering a measure to foster fundamental structural change in Middle Eastern and North African (MENA) societies. The EU therefore fails in presenting and promoting an alternative normative political vision distinct from the incorporation of women into the hierarchy of the existing market society.
\end{abstract}

\section{Keywords}

European Union, governmentality, women, neoliberalism, Arab Spring, empowerment 


\section{Introduction}

When thousands demonstrated for a greater say in their own governance in capitals across the Southern Mediterranean region in the 'Arab Spring' of 2011, the European Union's (EU) bustling activities to remedy its perceived weak political profile resulted in a review of the European Neighbourhood Policy (ENP) and the launch of a supposedly politicized 'New Response to a Changing European Neighbourhood' (European Commission 2011). Civil society actors play a central role in this declared new approach to democracy, political stabilisation and societal participation. In this regard, the EU emphasizes the importance of women as 'drivers' of reform processes in post-Arab spring societies. Therefore, the EU intends to empower women in the Middle East and North Africa (MENA) by, for example, launching the 'Spring forward for Women' (SfW) initiative, a joint European Union - United Nations (UN) Women programme. While the EU's focus on the economic empowerment of women is generally in line with the dominant concept of politicized development cooperation - assuming a spill-over from economic prosperity to political freedom - the implications of women's empowerment as a governmental instrument are remarkably understudied. There is limited knowledge about what the EU's external governance means for women in terms of empowerment in the post-Arab Spring era. Furthermore, we need a more refined theoretical conceptualisation of how to study the effects of empowerment as a governance instrument. Reconsidering the promised emancipatory potential of the empowerment tool designed to liberate women from (male) domination requires investigating the actual power dimension of empowerment. A number of studies argue that gender equality instruments actually only reconfigure power relations instead of contributing to significant economic, political and social change for women (see Oksala 2013). While these works draw attention to an important theoretical and empirical issue, the precise mechanisms and implications of empowering remain elusive.

Building on Michel Foucault's studies of governmentality (Foucault 2007, 2008, 2010), this article considers the following question: what kind of effects has women's empowerment as a technology of governing? The article deploys the Foucauldian concepts of 'biopower/biopolitics' to develop a comprehensive approach to the study of empowerment as a technology of power. As I will argue, empowerment is part of a neoliberal governmentality targeting both individual women and the entire female population. In contrast to the overemphasis of women's empowerment as an universal remedy for all societal problems in terms of underlining that empowerment 'is a question of democracy and good governance' and 
'part of the formula for economic progress' (European Commission 2015: 4), this article considers the disciplinary and control features of empowerment at the core of neoliberal instruments. While the extensive debate over whether the EU is a 'normative power Europe' (Manners 2002) and a promoter of political freedom and democracy in the neighbourhood (see Kurki 2011; Malmvig 2006; Powel 2009; Teti et al. 2013) is predicated on the existence of predefined political norms, the article shows that the EU's approach to empowerment promotes the rationality of a market society that fills the political dimension with a logic of economic processes. The emerging, depoliticized female subjectivities obstruct the realisation of political and social reforms envisaged by feminism because it promotes incorporating women into existing hierarchical structures. The functional freedom at work in empowerment is different to a normative freedom that supposedly informs the EU's external actions: while political freedom is optional, functional freedom is essential for neoliberal governance.

The article particularly contributes to a theoretical-conceptual understanding of women's empowerment as a contemporary instrument of the EU's external governing in the southern neighbourhood. In this regard, it is important to emphasize that the article strives to make intelligible the macro-structural causes and consequences of empowerment practices. The criticism provided by this article is directed at the (re-)production of domination and economic exploitation through the suggested empowerment approach. Nevertheless, I am aware that many of the analysed measures described are welcomed by participating women and might originate in the normative intention to improve the life of women in MENA countries. The perspective offered is therefore neither intended to reveal the ultimate truth about empowerment programmes, nor does it claim to be a privileged answer to the question of what is 'best' for women in the post-Arab Spring era. Instead, it analyses the power relations emerging in technologies of governing and the contingency of rationalities dominating specific conceptions of life as the basis of women's empowerment. The objective of this article is hence narrower than feminist-normative studies in the sense that it considers the power of empowerment without promoting a specific emancipatory rationality. At the same time, it is broader in investigating the macro-political implications of women's empowerment as an instrument of external governance.

The remainder of the article is structured as follows: the first section introduces the notion of governmentality and elaborates on how to understand women's empowerment as a neoliberal technology of governing. The second section analyses the governing of gender in terms of biopolitics, targeting the construction of female economic subjectivities and the measurement 
of the female population. The article concludes that the EU's use of women's empowerment fails to deliver on its promise of acting as a normative power in external relations. Instead of offering an alternative political rationality to the dominant neoliberal model of a market economy, it promotes the inclusion of women into existing hierarchies of male-dominated conduct based on bio-power.

\section{Governmentality: Neoliberal governing in practice}

Governmentality, as stated by Foucault, is 'the ensemble formed by institutions, procedures, analyses and reflections, calculations, and tactics that allow the exercise of this very specific, albeit very complex, power that has the population as its target, political economy as its major form of knowledge, and apparatuses of security as its essential technical instrument' ( 2007: 108). Governmentality therefore represents neither a coherent approach to governing populations nor a theoretical passe-partout to be applied to all facets of human practices. It is a perspective on interplaying rationalities as a 'form of knowledge' and technologies and techniques 'as essential technical instruments' developed in a specific socio-historical context. In this regard, Foucault's conceptualisation of governmentality is first and foremost an investigation of government approaches in the transition from liberal to neoliberal government. What does analysing governmentality mean in this regard?

Rationalities, as one aspect of governmentality, are social practices that discursively construct the means and ends of governing (Gordon 1991: 3; Merlingen 2006: 22; Rose and Miller 2008: 29), while 'technologies of government' (Foucault 2007: 9; Miller and Rose 1990: 8) are approaches comprising techniques to assess, measure, report, quantify, or calculate. In general terms, governmentality as a 'regime of practices' (Foucault 1991: 75) represents the technological translation of assessments of governability into a common government language, often based on quantitative indicators and benchmarks (Larner and Le Heron 2004: 218). Conceptualising this connection between rationalities and technologies, governmentality studies intend to refrain from reproducing a sequential logic of stable knowledge shaping actions. Taking the 'translatability' (Rose and Miller 2010: 280) of rationality and the process of operationalisation through instruments seriously also means considering to what extent rationality emerges in technologies. Therefore, the unique contribution of studying governmentality does not lie in revealing an omnipresent, concealed, and pre-existing ideology 
or 'hidden governmentality' (Kurki 2011: 360,362) such as neoliberalism, but in systematically exploring specific neoliberal technologies and their effects. Therefore, the crucial added-value of studying governmentality is Foucault's conceptualisation of power practices, targeting individuals and the entire population (see Dreyfus and Rabinow 1983: 133-135).

In this regard, Foucault notes that technologies of power comprise 'the disciplines of the body and the regulations of the population' (Foucault 1990: 139), the latter being formed by 'regulatory controls: a bio-politics of the population' (Foucault 1990: 139 italics in original). While this could imply a differentiation between discipline and regulation as two types of power that represent a chronological sequence of developing government technologies, Foucault emphasizes that there are 'diverse techniques for achieving the subjugation of bodies and control of populations, marking the beginning of an era of "bio-power" (Foucault 1990: 140). Hence, bio-power is not solely reserved for studying the control, regulation and subjectification (subjectivation) of individual bodies, although the term seems to suggest just this. It is therefore important to note that the neoliberal governmentality of the present entails elements of regulation (of the population) and discipline (of the body) that now, however, have the form of an 'action at a distance' (Rose and Miller 2010: 278), distinguishing them from direct interventions. Furthermore, the productive and constitutive quality of power allows for investigating conceptions of neoliberalism, gender governance, or development policy beyond the ideological dichotomy of right or wrong. Analysing how 'a regime of truth form[s] an apparatus (dispositif) of knowledge-power' (Foucault 2008: 19) reveals the mechanism that produces 'truth' and links supposed 'best practices' to specific technologies of governing. In this respect, women's empowerment should not merely be considered as an element of the neoliberal paradigm that fails to address the 'true' reasons for inequality and male domination but as a governmentality, a set of practices, that structures our understanding of how a 'normal' social reality and life ought to be.

Although governmentality concepts allow for a thorough analysis of how women are 'normalized' (Foucault 2007: 56-57) to conform to an optimal model, Foucault was widely criticized by feminist scholarship because he did not focus specifically on women or female subjectivities (see Amigot and Pujal 2009: 657-663; Deveaux 1994). While an elaborate discussion of the uneasy relation of Foucault and feminism is beyond the scope of this article, it should be noted that a body of studies have argued for the value of governmentality and biopower for analysing gender in governmental arrangements (Oksala 2013; Dean 2015; Foster 2011; Munro 2003; Prügl 2015). Although Foucault has failed to explicitly consider the 
situation of women, his take on bio-power as the basis of neoliberal governmentality opens promising avenues for research on gender. Oksala, for instance, shows how mainstream or popular feminism has largely adopted the neoliberal discourse of women's responsibility to optimise in order to become competitive and successful in the market economy (Oksala 2013). While the mechanism of subjectification, making individuals to fit with the existing order of neoliberal governmentality, is similar for women and men, the rhetoric about the empowerment to Western 'superwomen' aims specifically at the (mostly economic) optimisation of women as a paradigm of development policy (see Hickel 2014).

With regard to women during the Arab Spring, a substantial strain of research concentrates on the role of individual agency and various non-governmental groups during and after the uprisings, criticising that neither the domestic discourse in the affected societies nor the Western governmental or media discourse pays significant attention to the role of women (Lewinski and Mohammed 2012; McGarty et al. 2014; Wolfsfeld et al. 2013). Furthermore, studies highlight that the mainly Western dominated discourse has two distinct consequences: first, it promotes and reproduces an understanding of women as passive, apolitical and suffering, fundamentally lacking the potential for independent agency (Al-Ali 2012; Khalid 2015; Khalil, 2014; Moghadam 2014). Second, this discourse normatively overemphasizes the 'like-mindedness' and 'modernity' of women and their potential to modernize further according to Western standards (Sjoberg and Whooley 2015: 269). Moreover, while the promotion of gender equality and women's empowerment (GEWE) is increasingly mentioned as an important external relations objective, the EU appears to be personally, conceptually and structurally ill-equipped to deliver on gender mainstreaming. Concepts of gender are poorly understood by responsible staff and neglected as operational priority. In that, a review report concludes that ' $[\mathrm{t}] \mathrm{his}$ is a systemic failure, with the EU's GEWE commitments remaining as little more than rhetoric' (COWI et al. 2015: ix). As a further assessment report commissioned by the Evaluation Unit of the Directorate General for Development and Cooperation (EuropeAid) noted in 2013, 'despite the Commission's overall policy commitment to mainstream gender equality (including the development of a specific toolkit), the analysis of the regional programmes' documents shows that there is no evidence of a systematic integration of gender in the different interventions' (Development Researchers' Network (DRN) 2013: 60), particular with regard to the ENP South. In this regard, it is questionable to posit that 'the EU has become a major gender equality promoter in the neighbourhood' (Kunz and Maisenbacher 2015: 7), and the practice of women's empowerment in MENA seems to prove once more the failure of the EU to implement a 
comprehensive normative political agenda while the substantial economic adjustment programme widely criticized in relevant literature remains untouched (Bicchi 2011; Holden 2011; Seeberg 2010; Freyburg et al. 2009; Kausch and Youngs 2009; Montanari 2007; Teti 2012; Tömmel 2013; Bicchi and Voltolini 2013).

The more fundamental problem, however, concerns the effects associated with the EU's practice of empowerment. While the existing literature partly raises important points regarding the situation of women in MENA, it fails to problematize the power structure of empowerment. The promotion of empowerment as a default option for feminist studies often lacks reflexivity in terms of the role of agency and the different facets of freedom. For instance, research focussing on Euro-Mediterranean security relations as a gendered field argues for the 'promotion of individual and societal securities through empowerment' as a possible solution to the 'gendered power hierarchy' (Bilgic 2015: 334). However, what if we consider empowerment as part of the neoliberal repertoire of development instruments, infusing the rationality of the market into the socio-political domain? The creation of the 'neoliberal feminine subject' (Oksala 2013: 40) as an 'entrepreneur of the self' (see Foucault 2008: 226) who internalizes success, failure, and optimisation as central categories of the neoliberal social model blurs the distinction between political norms and economic-societal normality. The decisive point is therefore neither whether women are constructed as active or passive nor which discourse is fostered or silenced - it is how agency and freedom are operationalized as a technology of power. The general tension between normative political expectations and the functional face of the Euro-Med cooperation is mirrored in asking whether economic and political empowerment are indeed two sides of the same coin. In other words, what is the rationality of empowering women in the EU's approach? This points to the important role of the (feminine) subject in the deployment of empowerment as an instrument. As we will see in the following, freedom plays a decisive role in this context.

\section{Female agents for change? The EU's practice of empowerment}

The different programme initiatives and actions meant to empower women in the Mediterranean are (partly) EU funded or coordinated by the EU and its regional initiatives such as the Union for the Mediterranean (UfM). They are often executed in cooperation with the UN, local NGOs and other institutions. While there is a plethora of activities, the aim of the analysis is not to 
deliver a detailed and systematic account of the EU's gender policy in MENA, which is beyond the scope of this article. Rather, it offers insights into the practice of women's empowerment as an illustration of the theoretical conceptualisation, focussing on the two dimensions of biopower: the formation of economic subjects in terms of the empowerment to individual agency and the measurement of the female population. Before beginning this discussion, however, the following sub-section further substantializes the theoretical argument about the functionality of freedom.

\section{Empowerment to functional agency}

If I employ the word "liberal", it is first of all because this governmental practice in the process of establishing itself is not satisfied with respecting this or that freedom, with guaranteeing this or that freedom (...) It is a consumer of freedom inasmuch as it can only function insofar as a number of freedoms actually exist (...) The new art of government therefore appears as the management of freedom, not in the sense of the imperative: "be free", with the immediate contradiction that this imperative may contain. The formula of liberalism is not "be free" (Foucault 2007: 63).

Foucault's words above illustrate that neoliberal governance requires functional freedom as a condition of operation. This implies that the existence and production of freedom is essential for governmentality arrangements. The functional freedom that is the cornerstone of neoliberal governing, however, is different from political freedom in that emancipation as well as social and political participation are absorbed by the population's functional role in governmentality. A central concept in this context is 'governing through freedom' (Dean 2002, 2007; Walters and Haahr 2005: 44). Technologies work on the basis of various degrees of freedom, particularly in the arrangement of 'advanced liberal government' (Dean 1999: 164-165), in which the application of 'technologies of the self' (see Lemke 1997: 261-265) are central. The rationality of the neoliberal management of freedom primarily focuses on the optimisation of individuals and is linked to subjectification. Governmentality studies have argued that 'the subject of expertise is now understood (...) as an individual who lacks the cognitive, emotional, practical and ethical skills to take responsibility for rational self-management' (Rose and Miller 2008: 106). 
The widespread empowerment to functional agency is at the core of this reconfigured power of neoliberal governance. As Prügl argues '[b]ecause it helps produce free individuals, feminism contributes to the possibility of governing through freedom' (Prügl 2011: 85). In fact, the empowerment of women is widely framed along the lines of economic empowerment, for example through so-called 'smart economics' (World Bank 2011; World Bank 2006). This approach has been criticized inter alia for shifting the responsibility for delivering on development goals to individual female actors, while neglecting structural reasons for the inequality, discrimination against, and poverty of women (Roberts and Soederberg 2012; Chant and Sweetman 2012). Nevertheless, the EU states in the 2015 Joint Staff Working Document that '[g]ender equality and girls' and women's empowerment are part of the formula for economic progress. Girls' and women's economic empowerment is a driver of development' (European Commission 2015).

Similarly, the UN's Women's Empowerment Principles, introduced on International Women's Day 2010, 'emphasize the business case for corporate action to promote gender equality and women's empowerment and are informed by real-life business practices and input gathered from across the globe' (UN Women 2016). What appears and is sold as strengthening the independence and socio-economic status of women through participation in the labour and financial market (e.g., through microfinance), however, often results in exposure to new economic-financial and social risks (Charness and Gneezy 2012; Maclean 2013; Marlow and Swail 2014; Roberts and Soederberg 2012). The concept of empowerment is therefore fundamentally concerned with enabling women to become more competitive and attain better positions in the existing hierarchy, a form of functional emancipation, for example, by promoting 'education, training and professional development for women' (UN Women 2016). Here, empowerment is based on an understanding of power as domination that can be simply overcome by striving for a higher degree of perceived independence.

In sum, analysing women's empowerment as a technology of governance should first consider the disciplining of individual bodies in neoliberal forms of self-optimisation, such as training and education. Second, it should consider the bio-political conduct of the female population with regard to control, assessment and evaluation. The following sub-section sheds more light on empowerment and the mechanism of optimising women to become 'valuable' economic subjects. 
The Union for the Mediterranean and the ENP, the most important parts of 'the system of governance created in EuroMed' (Cardwell 2011: 221), are based on previous EU activities and a comprehensive acquis communautaire, which is otherwise promoted through the Union's enlargement, stabilisation and association processes. Recent initiatives to promote gender equality and women's empowerment in the southern dimension of the ENP rest on the pre-Arab Spring programme segments of EU-Mediterranean relations, established in the context of the 1995 Barcelona Process. The empowerment of women was initially a priority theme in the EuroMed Five Year Work Programme adopted by the 2005 'Barcelona Summit of Heads of State and Government'. Following this summit, two ministerial conferences on 'strengthening the role of women in society' were held in the UfM framework in Istanbul in 2006 and in Marrakesh in 2009. The Third Union for the Mediterranean Ministerial Conference on 'Strengthening the Role of Women in Society' was held in September 2013.

The conclusions of the second conference focused on civil and political, economic, and cultural and social rights. The commitments notably emphasized inter alia the intention to "promote women's entrepreneurship by (...) training and networking and encourage financial institutions to tailor products to women's needs, in particular by providing micro-credit; promote modules to improve economic and financial management skills for women entrepreneurs, investing in women's economic participation as "smart economics"; promote gender responsive budgeting' (Union for the Mediterranean 2009: 5). The EU's rationale for training economic subjectivities is therefore in line with the dominant approach to the empowerment of women in development cooperation, as represented, for example, by the aforementioned concept of 'smart economics' introduced by the World Bank's Gender Action Plan entitled 'Gender Equality as Smart Economics' in 2006.

How does women's empowerment as a technology of power directed at individuals function in MENA? First of all, it aims at the integration of women into the labour market using a doubletrack approach. This approach is based on a subjectification that feeds a Western-style leadership vision for a very limited number of women while offering basic training options for the majority. In this regard, the EU's approach is a mixture of high-profile but low-scale initiatives and various basic skills education programmes. This can be illustrated through considering recent UfM initiatives to empower women (see table 1). 
Table 1: UfM Women's Empowerment Projects

\begin{tabular}{|l|l|}
\hline Project & Year \\
\hline Women's Right to Health - The WoRTH Project & 2016 \\
\hline $\begin{array}{l}\text { Promoting women's empowerment for inclusive and sustainable industrial } \\
\text { development in the MENA region }\end{array}$ & 2015 \\
\hline WOMED: the “next generation of leaders" & 2015 \\
\hline $\begin{array}{l}\text { Forming Responsible Citizens - Promoting citizenship education to prevent school } \\
\text { violence, particularly against girls and women. }\end{array}$ & 2014 \\
\hline Developing Women's Empowerment & 2013 \\
\hline Skills for Success - Employability Skills for Women & 2012 \\
\hline Young Women as Job Creators & 2011 \\
\hline
\end{tabular}

Table 1 demonstrates that UfM-coordinated programmes provide for a number of specialized training opportunities designed to qualify women and girls to become 'the next generation of leaders'. Along similar lines, the two-week 'WOMED Promoting women's leadership' programme offers short-training programmes at Sciences Po Paris for twenty-two young women. However, more often, EU-funded or -coordinated programmes only provide for basic employability skills. The 'Skills for Success' programme for instance, 'will provide disadvantaged, unemployed, secondary-level educated women with the necessary skills, knowledge and tools to enter the labour market' (Union for the Mediterranean 2016b). It is part of the 'Mediterranean Initiative for Jobs (Med4Jobs)' considered as UfM's 'flagship' initiative.

In theoretical regards, this idea of empowerment as training and optimisation precisely conforms to the neoliberal subjectification of the homo reconomicus as a rational actor. In Foucault's words, '[h]omo œconomicus is someone who is eminently governable. From being the intangible partner of laissez-faire, homo ceconomicus now becomes the correlate of a governmentality which will act on the environment and systematically modify its variables' (Foucault 2008: 270-271).

The inclusion of women into the logic of the rational male actor, the Foucauldian "homo ceconomicus as entrepreneur of himself' (Foucault 2008: 226) characteristic of the gendered discourse of economic-financial success, is closely related to perceiving civil society as 'a 
concept of governmental technology' (Foucault 2008: 296) and the place where the imagined rational actor performs self-optimisation. In fact, the UfM notes that female 'entrepreneurship is an untapped source of growth, prosperity and poverty reduction, as well as being fundamental to women's empowerment for creating more equitable societies' (Union for the Mediterranean 2016a). In this regard, the various 'training opportunities' offered to women, often delivered by NGOs as the recipients of EU funding, are at the heart of the EU's civil society strategy. The EU notes that '[i]n the Southern Neighbourhood, civil society plays a key role in several countries in the implementation of social programmes funded by the EU (literacy programmes, care for children, gender equality, etc.)' (European Commission 2014: 9).

The professional co-optation of feminist movements on the basis of Western approaches to development and modernisation in the MENA region is what Jad referred to as 'the NGOization of the Arab Women's Movements' (Jad 2003) more than a decade ago. ${ }^{1}$ In fact, civil society in terms of NGOs representing women's interests is presented as the ultimate remedy for all problems associated with authoritarian government, corruption, lack of democracy, and gender inequality. Conceptualising a female civil society - in contrast to the male dominated state apparatus - as the primary location of economic activities inscribed in neoliberal governmentality, however, challenges its capacity to serve as a facilitator of political participation, cultural identity formation and public deliberation. This is similar to overemphasising civil society as a global democratisation concept on the inter-state level (see Bartelson 2006).

The fact that the current funding of women's empowerment implemented by local NGOs does not take place on 'a clean slate upon which to remould social relations through the ending of an abusive authoritarian regime' (Johansson-Nogues 2013: 405) as suggested by some, further aggravates the situation. The often criticized state-centric approach of the pre-Arab Spring ENP, which mainly used governmental channels to fund activities and hence relied on cooperation with the authoritarian regimes (Tassinari and Holm 2010; Bicchi 2006), is continued through funding practices that stabilize the existing influence of 'state-sanctioned women's groups (...) bound up with the nationalist agendas that co-opted feminist agendas insofar as they could serve the state's purpose' (Khalid 2015: 167).

In the MENA context, considering civil society as a homogenous arena of Western-likeminded dissidence ignores the diversity of interests and actors and leads to a continuation of the preArab Spring governmental conduct of civil society as a state-controlled project of pseudo- 
democratisation. While the putatively reformed approach of 'A New Response to a Changing Neighbourhood' (European Commission 2011) adopted in the heyday of the Arab Spring promised a central role for civil society, the EU even failed to consult with NGOs in the MENA region during the document's drafting process (see Oxfam International 2011). Moreover, including the empowerment of women within this model of civil society transfers the logic of economic rationality onto them. As aforementioned, the construction of women as the primary measure of governmental interventions, entailing the expectation, education and actual training to become homines oeconomici, has crucial implications for the processes of subjectification and agency formation taking place in an institutionalized civil society. While the situation of women in terms of socio-economic and civil-political rights is certainly problematic in MENA, their empowerment to functional agency merely substitutes the dominance of disciplinary power with the more diffuse and self-inflicted power relations of neoliberalism as the ideal of a Western-style modern society. Empowerment essentially transfers the responsibility for a life of 'success', 'competitiveness' and 'resilience' to the individual level. In this respect, the state or society is not to be held accountable for any failures of women to optimise or use their 'freedom' effectively and reasonable.

Furthermore, as of August 2016, the UfM programme 'Med4Jobs' (see table 1) supported twelve projects carried out by NGOs in different MENA countries, for instance. The programme is inter alia funded by PepsiCo, thereby raising the question of whether such initiatives only reinforce the widespread problem of 'the feminization and informalization of labour' (UNRISD 2005, 67) in the sense of expanding of low-wage work, while women (and men to a lesser extent) are merely trained to provide a pool of cheap labour in those countries targeted by global companies. If women entered the structurally inefficient labour market in MENA countries in significant numbers, pressure on wages and employee rights would certainly increase. In this scenario, 'employability' as an objective of empowerment initiatives is a synonym for 'governability' based on the politics of truth about accepting one's role in the globalized economy, shaping conceptions of what a 'normal' life and economic existence ought to be.

Nevertheless, the rationality of empowerment as a technology of economic governance enabling the exploitation of women's economic potential is widespread. In September 2015, the 'Spring Forward for Women'-funded 'Arab Women Economic Empowerment Network' (Khadija) was launched to foster the participation of women in the labour market, aiming at promoting economic growth. In the words of Mohammad Naciri, Regional Director of the UN 
Women Regional Office for the Arab States, '[t]he region has made significant investments in women's education in the last decade. However, the return on investment is still under-utilized due to their limited economic participation (...) Through this network, we are more capable of maximizing our region's human resources and capturing opportunities for growth' (Spring Forward for Women Programme 2015a). The specific power-knowledge relationship of the neoliberal governmentality of MENA women's empowerment is therefore predicated on constructing the 'desire' for success (see Hickel 2014: 1367), measured against the Western model of the 'business case' for empowerment, channelling the modernisation of the self to gain access to the advanced labour market.

Empowerment as a technology of power provides for a governmental disciplinary instrument in the Foucauldian sense that trains and controls individual female bodies. The concept of employability safeguards governability in two ways: first, it allows for the potential integration of women into an existing structure of male-dominated labour based on the governing of the self if women accept their offered roles, either as 'future leaders' or as 'economic misfits' to be optimised. First, this reinforces existing hierarchies and structural inter- and intra-gender inequalities, as well as the logic of competition. Second, it is an instrument of political stabilisation that sells economic incentives in terms of a putative career or an additional income source as evidence of reform. The rationality that emerges in these practices emphasizes growth as a central neoliberal paradigm. The EU clarifies that women's empowerment and ownership 'can also contribute to stronger and more inclusive economic growth that benefits society as a whole (...) closing the labour force gender gap by 2030 could yield a potential average gain of $12 \%$ to the size of the total economy across OECD countries' (European Commission 2015: 8). Therefore, GDP growth is presented as the key objective of development policies implemented by the EU and national governments as well as actors such as the UN. Overemphasising growth and free market societies becomes an important vehicle of realising empowerment, understood solely as gaining access to the labour market (and the financial market in terms of microfinance, for instance). This understanding of empowerment, however, is structurally averse to demands for social equality, welfare reforms, and fundamental political-systemic change. In this sense, the truth constructed by the EU's women's empowerment programmes presents societal problems and solutions only in economic terms. The highly complex issue of gender and women's equality is operationalized and thereby simplified by economic indicators such as GDP. This means that the sphere of politics is colonized by economic rationalities and is pushed to the individual level, portraying women as responsible for their own fate. 
The marketisation of the political sphere (see Foucault 2008: 131) therefore also has implications for the promotion of fundamental norms such as human rights, a key objective of the EU in the southern neighbourhood. Reframing the political in economic terms means that norms of individual freedom are understood as functional rights that ensure a certain degree of liberty necessary to act as an entrepreneurial subject. In this regard, gender equality is reconstructed by technologies, such as empowerment, as a normative principle protecting the status of women as a functional element in the market economy while reproducing existing social inequalities. The Commission identifies '[p]romoting the economic and social rights / empowerment of girls and women' (European Commission 2015: 4) as one of four pivotal areas of gender empowerment and women's equality in its most recent working document. This not only indicates the absence of political empowerment as a strategic priority, but it also emphasizes a dichotomy between economic and social rights that materializes in the rationality of empowerment promoted by the EU. This basically risks degrading basic civil and political rights in favour of building a vague framework to be filled with economic requirements and desires.

Transferring economic principles and methods to normative issues such as gender equality and women's empowerment is also perceptible in the second dimension of bio-power, the assessment of populations. The following sub-section considers this as the second layer of the EU's biopolitical governing of women as a distinctive group in MENA countries.

\section{Biopolitics and the measurement of the female population}

As argued in the conceptual section, the bio-power of neoliberal governmentality emerges as the interplay between the disciplinary formation of individuals and the control, assessment, and evaluation of an entire population. The measurement of women's empowerment and gender equality is rarely considered in this context, although the statistical evaluation of all aspects of life is at the core of biopolitical control. These evaluations, and the resulting 'governing by numbers' (Grek 2009; see Hansen and Mühlen-Schulte 2012), are the most fundamental techniques of 'government at a distance' (Rose and Miller 2008: 34). The practice of actors such as the Organisation for Economic Cooperation and Development (OECD), UN and relevant evaluation units are particularly important for development policy. There are tendencies to harmonize and share 'best practices' of evaluation, facilitated by institutions such as the DAC Evaluation Resource Centre (DEReC), a global network hosted by the OECD as a subsidiary body that 'serves as a platform for learning and co-ordination, and enables members 
to work together to improve the quality of evaluations and harmonize evaluation processes' (OECD 2010: 1).

Measurement is part of empowerment as a technology of power in two regards: first, the allocation of EU funds, for example, through the European Neighbourhood Policy Instrument (ENI), requires a system of benchmarks and indicators to evaluate success. The EU has not yet developed a fully-fledged evaluation approach for GEWE (see COWI et al. 2015), but introducing measurable objectives and indicators has become a key target (European Commission 2013). Transferring the existing technical framework to the dimension of GEWE will further strengthen the functional perspective of 'modernising women' (Moghadam 2014) in the aftermath of the Arab Spring. This means that the perceived success of technologies such as the empowerment of women through lending, particularly if it is measured in numerical terms, simplifies the complexities of social power-relations. For example, whether an increase in the number of women using micro-finance instruments or a low loan loss rate is actually a success is less clear than it might seem. Novel risks and vulnerabilities induced by instruments such as microcredits often remain undetected. This is what Engle Merry and Wood call 'the paradox of measurement: to make something known it must be countable, but if it has not already been translated into commensurable and quantifiable terms, it is difficult to count and may remain unnoticed and uncounted' (Merry and Wood 2015: 205). The implications of approaches to measurement such as the Women's World Banking 'Gender Performance Indicators' (Women's World Banking 2015) as part of the empowerment to putative financial responsibility and independence should be reconsidered in this regard.

Furthermore, the EU's functional concept of agency leads to allocating funds only to those initiatives that fall within the underlying margins of efficiency, economic progress, and neoliberal reform. This also means that women who do not fit into the concept of functional agency are constructed as passive, weak and dependent subjects that are either willing to be optimised or left out of major funding schemes if they have a different understanding of their role.

Second, measurement is part of the dominant politics of truth regarding conceptions of a normal woman's life. Foucault provided a conceptualisation of the mechanisms of measurement in the 'apparatuses of security' (Foucault 2007: 57) that emerged with the administrative expansion of government and which he distinguishes from the disciplinary normalisation targeting individual bodies. The aim is now to produce statistically informed understandings of the 
'normal distribution' and the 'operation of normalization consists in establishing an interplay between these different distributions of normality and [in] acting to bring the most unfavorable in line with the more favorable' (Foucault 2007: 63). In other words, the statistical evaluation of women's empowerment produces quantitative indicators that are compared to the 'normal' distributions represented by the Western optimum. The key to biopolitical assessment is hence the construction of indicators and reporting techniques.

In the Annex of the Joint Staff Working Document, the EU emphasizes that '[i]n order to ensure consistent and rigorous application of reporting methodologies and indicators, the Commission services and the EEAS will develop detailed guidance' (European Commission 2015: 18). Moreover, the document provides a detailed table that gives clear examples of how the EU's reporting system works with respect to women's empowerment. It is apparent that the impact assessment is strongly focused on efficiently obtainable data such as the "number of job descriptions that contain gender equality as an area of responsibility', the 'number of programme evaluations per year that include an assessment of impact on women and girls', the 'percentage of results disaggregated where relevant by sex in Results Framework(s)', the 'number of research projects co-financed by EU (EUD/MS) on gender related issues', the 'number of projects building awareness of local and national media on gender issues in partner countries and supported by EU', the 'number of EU delegations awarded Gender Awards', the 'number of honour killings', or the 'percentage of women aged 20-24 years old who were married before their 18th birthday' (European Commission 2015: 20-25, 42). Whether these indicators indeed 'provide an indication of progress' or 'allow for indication of EU contribution' (European Commission 2015: 42) is questionable considering the limited conception of GEWE they construct. Furthermore, any evaluation based on these indicators only measures specific situations as the outcome, leaving processes unconsidered; it also lacks a clear understanding of causality between means and ends.

Although the EU argues that it intends to "[invest] in, and [use], systematic high quality gender evidence and analysis to contextualize and tailor approaches to the specific social, political and demographic characteristics of the partner country where the EU operates' (European Commission 2015: 14), these indicators appear as another example of the EU's 'one size fits all' (Bicchi 2006) approach, widely criticized in the EU's Mediterranean policy (Tassinari and Holm 2010; Haukkala 2008; Tömmel 2013; Browning and Joenniemi 2008). This contrasts with the ENP's central paradigms of 'joint-ownership' and 'differentiation' that are also reproduced in the SfW documents, underlining that the programme is 'building on local 
initiatives in selected countries, with the recognition that sustainable change must be locallyowned and led' (UN Women 2015).

Considering the biopolitical conception, measuring the female population based on such indicators is important to understanding the construction of a normal life. These evaluations and the resulting statistical distributions of the normality of women in MENA countries are measured against a pre-existing Western normal or optimal model. Statistical results that are assessed by the EU as unfavourable are discursively linked to macro-economic indicators such as GDP growth and establish the basis for the "processes of progressive training (dressage) and permanent control' (Foucault 2007: 57) targeting individual female bodies.

The interplay of the individual and population level as fields of bio-power is also obvious with regard to the EU's construction of a rationality of family and reproduction compatible with the neoliberal vision of economic productivity. In this regard, the technology of women's empowerment serves neoliberal governmentality by increasing female productivity as an element of economic growth. Whereas the subjectification of the 'entrepreneur of the self' is well-covered in relevant literature, the specific targeting of women in the development approaches of major actors introduces a novel set of implications. The biopolitical control of women based on essentialist concepts links women to questions of family planning and reproduction as influencing their functional role. The deployment of GEWE as an EU instrument of biopolitical control has been researched in the domestic context of European states. Repo argues that the EU 'expects women to replace the retiring male workforce by joining the labour market whilst at the same time reproducing the next generation of wageearners' (Repo 2014: 16). While gender politics in the most developed Western countries mainly aim at counteracting the perceived demographic challenge of ageing populations and declining birth rates, the situation in MENA and developing countries in general is constructed in adverse terms. Here, the problematisation is centred on the link between population growth, (youth) unemployment, and the traditional family as obstacles to fully tapping the economic resource of women. At the same time, population growth is considered as one of the primary reasons for unemployment and political instability in the MENA region.

This understanding is widespread in political discourses. For instance, a report by the Parliamentary Assembly of NATO on the 'youth bulge problem' in MENA countries concluded that 'NATO must increasingly strengthen and expand the political links and partnerships in the MENA region to stave off the dangers of instability which a youth bulge might bring to the 
populations of the NATO countries if its potential is not adequately tapped' (NATO Parliamentary Assembly 2010: 13). The ‘securitisation' (Buzan, Wæver, and Wilde 1998) of the 'youth bulge problem' is beyond the scope of this article. Nevertheless, the underlying rationality of problematising birth rates, sexuality and female roles in Arab states forms a dominant development discourse. For example, a report for the United Nations Development Programme, Regional Bureau for Arab States, concluded with regard to '[a] history of high fertility in the Arab region' that '[ $t]$ he reduction of high fertility and increases in the workingage population can create opportunities for economic growth if the right mix of educational, health, and labor-market policies are in place' (Mirkin 2013: 7).

Likewise, the EU clearly promotes a rationality that constructs a tension between existing conceptions of family and reproduction and participation in the market society. It emphasizes that '[i]ssues such as reconciliation between family and work are crucial to unlock women's economic potential and contribution to development' (European Commission 2015: 7). At the same time it highlights that women 'lack the knowledge required to make sexual and reproductive decisions responsibly' (European Commission 2015: 5). With regard to Egypt, for instance, the ENI Programming document notes that 'Egyptians are suffering from a weak economy, growing joblessness and increasing poverty and vulnerability (...) with a still very high annual population growth rate of 2.8\% in FY13 [Financial Year 2013], inclusion remains a multidimensional challenge for the Egyptian economy' (European Commission 2013b: 4).

This means that the EU constructs a twofold truth about reproduction: first, pre-modern family sizes and models obstruct the access of women to the labour market, which is linked to unsatisfying economic growth rates. Second, women lack the necessary knowledge to selfgovern their reproductive behaviour and require training to optimise to modern Western standards. I do not argue that reviewing and improving the health care dimension in MENA countries is irrelevant, but I stress in this context that the empowerment of women is presented as realized by acquiring a specific version of freedom, knowledge and life-style. This constructed truth about a woman's 'normal' life emerges in women's empowerment as a technology of power and serves to silence any alternative rationalities of the self potentially present in MENA countries. 


\section{Conclusion}

The EU's rhetoric about a new political approach as a response to the Arab Spring raised expectations that the EU's neighbourhood policy would intensify its political liberal-normative influence in the Mediterranean region and contribute to the political empowerment of women. This article argues that empowerment is not an instrument of liberation but a technology of neoliberal governmentality that empowers women with functional agency. The emerging rationality of individual freedom based on the formation of economic actors 'free' to operate within the set margins of a market society reproduces structural hierarchies and power relations. While it is conventionally stated that 'men's freedom (privilege, etc.) is contingent upon women's unfreedom' (Deveaux 1994: 236), the perspective on empowerment as an instrument of governmentality moves beyond the dichotomy of freedom and unfreedom.

Empowerment as technology of bio-power operates on two dimensions by disciplining individual bodies and controlling the population: first, the subjectification of women as economic subjects incorporates women into the basic rationality of governing through freedom. The indirect action at a distance works through the governing of the self - women are supposed to internalize the overall Western rationality of modernisation, self-optimisation, and education that is fundamental to the EU's programmes. While these measures might be welcomed by women and can improve their immediate socio-economic status, underlying structural factors of (social) inequality, gender division, and domination remain untouched. Furthermore, economic techniques such as microfinance expose women to novel risks and power-relations. Second, the empowerment of individuals interacts with the measurement of the female population in MENA countries. The article demonstrates that the rationality of statistical assessment and the governing by and of numbers in particular aims at enforcing a vision of empowerment based on the Western average 'normal' woman. This is closely connected to the biopolitical assessment of population and labour statistics that constructs a connection between family size, low participation of women in the labour market, and economic development.

In the context of the overall debate of the EU as a putative normative power, the study of women's empowerment also shows that programmes such as the ENP, Spring forward for Women, or the UfM's initiatives are the external effects of rationalising governmental processes that originate in the historical development of Western models of government. The 'regime of truth' (Foucault 2001: 131) constructing the rationality of a modern and optimised women finding her place in the global economic structure promoted by the EU is a de facto 
continuation of 'orientalism', constructing a 'reality whose structures promote the difference between the familiar (Europe, the West, us) and the strange (the Orient, East, them)' while constituting 'a set of constraints upon and limitations of thought' (Said 2003: 42) that silence alternative practices of female agency in MENA societies. The dominance of technicalfunctional cooperation constructs a narrative about so-called best practices for reforming societies and individuals in the Southern neighbourhood, containing a 'truth' about selfentrepreneurial empowerment as the only reasonable form of freedom. Deploying technical instruments is the ultimate power of normalisation that is nevertheless alien to promoting classical political liberalism in the EU and abroad. As a consequence of the global process of normalising conduct, the design, suitability, and context of applying the technology of empowerment remains unconsidered. The widely reproduced rhetoric about normative power Europe is more than the mere discursive legitimisation of rule: it becomes the very basis for implementing the technocratic dimension of neoliberal governance that is not about the vision of freedom it putatively promotes. Regardless of whether the ENP is actually meant to strengthen democratisation and individual rights, the EU's approach to empowerment predisposes it to promote functional agency merely flanked with basic rights, guaranteeing the effectiveness of governmental interventions. Even if the EU promoted understandings of women's empowerment that were not linked to efficiency, exploiting human resources, and economic growth, even if it developed new concepts of conduct to reconcile functional necessities and normative needs, it would still reproduce those power-relations inherent to the formation of individuals and the measurement of populations as long as it applies neoliberal technologies of government.

\footnotetext{
About the Author

Hendrik Huelss is a Post-Doctoral Researcher at the University of Kent. His research focusses on governmentality studies, the role of norms in IR, the EU's external relations, and foreign and security policy instruments. He also explores the normative dimension of EU-Japan relations.
} 


\section{Acknowledgements}

I am grateful to the Editors, two anonymous reviewers, Ingvild Bode and Toni Haastrup for their constructive and insightful feedback on earlier versions of this article.

\section{Notes}

${ }^{1} \mathrm{I}$ am indebted to an anonymous reviewer for bringing this reference to my attention.

\section{References}

Al-Ali, Nadje. 2012. "Gendering the Arab Spring.” Middle East Journal of Culture \& Communication 5 (1): 26-31.

Amigot, Patricia, and Margot Pujal. 2009. “On Power, Freedom, and Gender: A Fruitful Tension between Foucault and Feminism.” Theory \& Psychology 19 (5): 646-69.

Bartelson, J. 2006. “Making Sense of Global Civil Society.” European Journal of International Relations 12 (3): 371-95.

Bicchi, Federica. 2006. “'Our Size Fits All’: Normative Power Europe and the Mediterranean.” Journal of European Public Policy 13 (2): 286-303.

- 2011. "The Union for the Mediterranean, or the Changing Context of EuroMediterranean Relations." Mediterranean Politics 16 (1): 3-19.

Bicchi, Federica, and Benedetta Voltolini. 2013. "EU Democracy Assistance in the Mediterranean: What Relationship with the Arab Uprisings?” Democracy and Security 9 (1-2): 80-99.

Bilgic, Ali. 2015. "Hybrid Hegemonic Masculinity of the EU before and after the Arab Spring: A Gender Analysis of Euro-Mediterranean Security Relations." Mediterranean Politics 20 (3): 322-41. 
Browning, C. S., and P. Joenniemi. 2008. "Geostrategies of the European Neighbourhood Policy." European Journal of International Relations 14 (3): 519-51.

Buzan, Barry, Ole Wæver, and Jaap de Wilde. 1998. Security: A New Framework for Analysis. Boulder: Lynne Rienner Publishers.

Cardwell, Paul James. 2011. "EuroMed, European Neighbourhood Policy and the Union for the Mediterranean: Overlapping Policy Frames in the EU's Governance of the Mediterranean.” Journal of Common Market Studies 49 (2): 219-41.

Chant, Sylvia, and Caroline Sweetman. 2012. "Fixing Women or Fixing the World? 'Smart Economics', Efficiency Approaches, and Gender Equality in Development.” Gender \& Development 20 (3): 517-29.

Charness, Gary, and Uri Gneezy. 2012. "Strong Evidence for Gender Differences in Risk Taking.” Journal of Economic Behavior \& Organization 83 (1): 50-58.

COWI, ADE, and Itad. 2015. “Evaluation of EU Support to Gender Equality and Women's Empowerment in Partner Countries. Final Report.”

Dean, Mitchell. 1999. Governmentality: Power and Rule in Modern Society. London: SAGE.

—. 2002. "Liberal Government and Authoritarianism." Economy and Society 31 (1): 3761. 2007. Governing Societies: Political Perspectives on Domestic and International Rule. Maidenhead: Open University Press.

—. 2015. "The Malthus Effect: Population and the Liberal Government of Life." Economy and Society 44 (1): 18-39.

Deveaux, Monique. 1994. "Feminism and Empowerment: A Critical Reading of Foucault." Feminist Studies 20 (2): 223-47.

Development Researchers' Network (DRN). 2013. "Evaluation of the European Union's 
Support to Two European Neighbourhood Policy Regions (East and South).” Rome. Dreyfus, Hubert L., and Paul Rabinow. 1983. Michel Foucault: Beyond Structuralism and Hermeneutics. 2nd ed. Chicago: University of Chicago Press.

European Commission. 2011. “A New Response to a Changing European Neighbourhood. $\operatorname{COM}(2011) 303 . "$

. 2013a. "Gender Mainstreaming Continues to Be a Challenge for Development

\section{Cooperation."}

—. 2013b. "Programming of the European Neighbourhood Instrument (ENI) - 2014-

2020. Single Support Framework for EU Support to Egypt (2014-2015).”

—. 2014. "Neighbourhood at the Crossroads: Implementation of the European

Neighbourhood Policy in 2013. JOIN(2014) 12 Final."

- 2015. “Gender Equality and Women's Empowerment: Transforming the Lives of Girls and Women through EU External Relations 2016-2020. Joint Staff Working Document SWD(2015) 182 Final."

Foster, Emma A. 2011. “Sustainable Development: Problematising Normative Constructions of Gender within Global Environmental Governmentality." Globalizations 8 (2): 135-49.

Foucault, Michel. 1990. The History of Sexuality, Volume I: An Introduction. New York: Vintage Books.

—. 1991. "Question of Method.” In The Foucault Effect. Studies in Governmentality, edited by Graham Burchell, Colin Gordon, and Peter Miller, 73-86. Chicago: University of Chicago Press.

—. 2001. "Truth and Power.” In Power: Essential Works of Michel Foucault 1954-1984, Volume 3, edited by James D. Faubion, 111-34. New York: The New Press. . 2007. Security, Territory, Population. Lectures at the Collège de France 1977-1978. 
Basingstoke: Palgrave Macmillan. 2008. The Birth of Biopolitics. Lectures at the Collège de France 1978-1979.

Basingstoke: Palgrave Macmillan.

- 2010. The Government of Self and Others. Lectures at the Collège de France 19821983. Basingstoke: Palgrave Macmillan.

Freyburg, Tina, Sandra Lavenex, Frank Schimmelfennig, Tatiana Skripka, and Anne Wetzel. 2009. "EU Promotion of Democratic Governance in the Neighbourhood." Journal of European Public Policy 16 (6): 916-34.

Gordon, Colin. 1991. "Governmental Rationality: An Introduction." In The Foucault Effect: Studies in Governmentality, edited by Graham Burchell, Colin Gordon, and Peter Miller, 1-51. Chicago: Chicago University Press.

Grek, Sotiria. 2009. “Governing by Numbers: The PISA 'effect' in Europe.” Journal of Education Policy 24 (1): 23-37.

Hansen, Hans Krause, and Arthur Mühlen-Schulte. 2012. "The Power of Numbers in Global Governance.” Journal of International Relations and Development 15 (4): 455-65.

Haukkala, Hiski. 2008. "The European Union as a Regional Normative Hegemon: The Case of European Neighbourhood Policy." Europe-Asia Studies 60 (9): 1601-22.

Hickel, Jason. 2014. “The 'Girl Effect': Liberalism, Empowerment and the Contradictions of Development." Third World Quarterly 35 (8): 1355-73.

Holden, Patrick. 2011. "A New Beginning? Does the Union for the Mediterranean Herald a New Functionalist Approach to Co-Operation in the Region?" Mediterranean Politics 16 (1): 155-69.

Jad, Islah. 2003. "The NGOization of the Arab Women's Movements. Paper Prepared for the International Workshop Feminist Fables and Gender Myths: Repositioning Gender in 
Development Policy and Practice, Institute of Development Studies, Sussex, 2-4 July 2003." www.bridge.ids.ac.uk.

Johansson-Nogues, E. 2013. "Gendering the Arab Spring? Rights and (In)security of

Tunisian, Egyptian and Libyan Women." Security Dialogue 44 (5-6): 393-409.

Kausch, Kristina, and Richard Youngs. 2009. "The End of the "Euro-Mediterranean Vision."” International Affairs 85 (5): 963-75.

Khalid, Maryam. 2015. "The Peripheries of Gender and Sexuality in the 'Arab Spring.” Mediterranean Politics 20 (2): 161-77.

Khalil, Andrea. 2014. "Gender Paradoxes of the Arab Spring." The Journal of North African Studies 19 (2): 131-36.

Kunz, R., and J. Maisenbacher. 2015. "Women in the Neighbourhood: Reinstating the European Unions Civilising Mission on the Back of Gender Equality Promotion?" European Journal of International Relations, no. online first (December).

Kurki, Milja. 2011. "Governmentality and EU Democracy Promotion: The European Instrument for Democracy and Human Rights and the Construction of Democratic Civil Societies.” International Political Sociology 5 (4): 349-66.

Larner, Wendy, and Richard Le Heron. 2004. "Global Benchmarking: Participating 'at a Distance' in the Globalising Economy.” In Global Governmentality: Governing International Spaces, edited by Wendy Larner and William Walters, 212-32. London/New York: Routledge.

Lemke, Thomas. 1997. Eine Kritik der Politischen Vernunft: Foucaults Analyse der Modernen Gouvernementalität. Hamburg: Argument.

Lewinski, Marcin, and Dima Mohammed. 2012. "Deliberate Design or Unintended Consequences: The Argumentative Uses of Facebook during the Arab Spring." Journal 
of Public Deliberation 8 (1): 1-11.

Maclean, Kate. 2013. “Gender, Risk and Micro-Financial Subjectivities.” Antipode 45 (2): $455-73$.

Malmvig, Helle. 2006. "Caught between Cooperation and Democratization: The Barcelona Process and the EU's Double-Discursive Approach.” Journal of International Relations and Development 9 (4): 343-70.

Manners, Ian. 2002. “Normative Power Europe: A Contradiction in Terms?” Journal of Common Market Studies 40 (2): 235-58.

Marlow, Susan, and Janine Swail. 2014. “Gender, Risk and Finance: Why Can’t a Woman Be More like a Man?” Entrepreneurship \& Regional Development 26 (1-2): 80-96.

McGarty, Craig, Emma F. Thomas, Girish Lala, Laura G. E. Smith, and Ana-Maria Bliuc. 2014. "New Technologies, New Identities, and the Growth of Mass Opposition in the Arab Spring." Political Psychology 35 (6): 725-40.

Merlingen, Michael. 2006. European Union Peacebuilding and Policing : Governance and the European Security and Defence Policy. London/New York: Routledge.

Merry, Sally Engle, and Summer Wood. 2015. "Quantification and the Paradox of Measurement: Translating Children's Rights in Tanzania." Current Anthropology 56 (2): 205-29.

Miller, Peter, and Nikolas Rose. 1990. “Governing Economic Life.” Economy and Society 19 (1): $1-31$.

Mirkin, Barry. 2013. “Arab Spring: Demographics in a Region in Transition. Arab Human Development Report Research Paper Series.”

Moghadam, Valentine M. 2014. "Modernising Women and Democratisation after the Arab Spring." The Journal of North African Studies 19 (2): 137-42. 
Montanari, Marco. 2007. "The Barcelona Process and the Political Economy of Euro-

Mediterranean Trade Integration.” Journal of Common Market Studies 45 (5): 1011-40.

Munro, V. E. 2003. "On Power and Domination: Feminism and the Final Foucault."

European Journal of Political Theory 2 (1): 79-99.

NATO Parliamentary Assembly. 2010. "The Implications of the Youth Bulge in Middle East and Norht African Populations. 138 GSM 10 E Rev 3.”

OECD. 2010. “The DAC Network on Development Evaluation: Illuminating Development Results and Challenges." Factsheet.

Oksala, Johanna. 2013. "Feminism and Neoliberal Governmentality." Foucault Studies 16 (September): 32-53.

Oxfam International. 2011. "Power to the People? Reactions to the EU's Response to the Arab Spring." www.oxfam.org.

Powel, Brieg Tomos. 2009. "A Clash of Norms: Normative Power and EU Democracy Promotion in Tunisia." Democratization 16 (1): 193-214.

Prügl, Elisabeth. 2011. "Diversity Management and Gender Mainstreaming as Technologies of Government.” Politics \& Gender 7 (1): 71-89.

—. 2015. "Neoliberalising Feminism." New Political Economy 20 (4): 614-31.

Repo, Jemima. 2014. “Gender Equality as Biopolitical Governmentality in a Neoliberal European Union." Social Politics: International Studies in Gender, State \& Society, December, 1-22.

Roberts, Adrienne, and Susanne Soederberg. 2012. "Gender Equality as Smart Economics? A Critique of the 2012 World Development Report." Third World Quarterly 33 (5): 949_ 68.

Rose, Nikolas, and Peter Miller. 2008. Governing the Present: Administering Economic, 
Social and Personal Life. Cambridge: Polity. 2010. "Political Power beyond the State: Problematics of Government." The British Journal of Sociology 61 (SUPPL. 1): 271-303.

Said, Edward W. 2003. Orientalism. London/New York: Penguin.

Seeberg, Peter. 2010. "Union for the Mediterranean —Pragmatic Multilateralism and the Depoliticization of EU-Middle Eastern Relations." Middle East Critique 19 (3): 287302.

Sjoberg, Laura, and Jonathon Whooley. 2015. “The Arab Spring for Women? Representations of Women in Middle East Politics in 2011." Journal of Women, Politics \& Policy 36 (3): $261-84$

Spring Forward for Women Programme. 2015. "Launching the Arab Women Economic Empowerment Network 'Khadija.'” http://springforward.unwomen.org/en/news/launching-the-arab-women-economic-empowermentnetwork.

Tassinari, Fabrizio, and Ulla Holm. 2010. "Values Promotion and Security Management in Euro-Mediterranean Relations: 'Making Democracy Work' or 'Good-Enough Governance'?" 17. DIIS Working Paper.

Teti, Andrea. 2012. “The EU's First Response to the 'Arab Spring': A Critical Discourse Analysis of the Partnership for Democracy and Shared Prosperity." Mediterranean Politics 17 (3). Routledge: 266-84.

Teti, Andrea, Darcy Thompson, and Christopher Noble. 2013. "EU Democracy Assistance Discourse in Its New Response to a Changing Neighbourhood." Democracy and Security 9 (1-2): 61-79.

Tömmel, Ingeborg. 2013. “The New Neighborhood Policy of the EU: An Appropriate 
Response to the Arab Spring?" Democracy and Security 9 (1-2): 19-39.

UN Women. 2015. “Spring Forward for Women Programme : About.” http://springforward.unwomen.org/en/about.

. 2016. "Women's Empowerment Principles.” http://weprinciples.org/.

Union for the Mediterranean. 2009. "Conclusions: Second Ministerial Conference on Strengthening the Role of Women in Society." Marrakesh, 11th and 12th of November 2009. http://ec.europa.eu/external_relations/euromed/women/index_en.htm.

. 2016a. "Promoting Women Empowerment for Inclusive and Sustainable Industrial Development in the MENA Region.” http://ufmsecretariat.org/promoting-womenempowerment-for-inclusive-and-sustainable-industrial-development-in-the-menaregion/.

—. 2016b. "Skills for Success - Employability Skills for Women." http://ufmsecretariat.org/skills-for-success-employability-skills-for-women/.

UNRISD. 2005. “Gender Equality: Striving for Justice in an Unequal World.” Geneva.

Walters, William, and Jens Henrik Haahr. 2005. Governing Europe: Discourse, Governmentality and European Integration. London/New York: Routledge.

Wolfsfeld, G., E. Segev, and T. Sheafer. 2013. "Social Media and the Arab Spring: Politics Comes First.” The International Journal of Press/Politics 18 (2): 115-37.

Women’s World Banking. 2015. “Gender Performance Initiative.” http://www.womensworldbanking.org/research/gender-performance-initiative/.

World Bank. 2006. "Gender Equality as Smart Economics: A World Bank Group Gender Action Plan (Fiscal Years 2007-10).” Washington DC.

—. 2011. World Development Report 2012. Washington: The World Bank. 